\title{
The New Zealand Construction Contracts Amendment Act 2015 - For Better or Worse?
}

\author{
David Finnie ${ }^{1}$ and Noushad Ali Naseem Ameer $\mathrm{Ali}^{2}$ \\ ${ }^{1}$ School of Architecture, Building and Engineering, Otago Polytechnic, New Zealand \\ ${ }^{2}$ School of Engineering and Advanced Technology, Massey University, New Zealand
}

\begin{abstract}
Adjudication has been statutorily introduced as an alternative dispute resolution method in 14 jurisdictions including New Zealand. Whilst adjudication under the New Zealand Construction Contracts Act 2002 has been hailed a success, further refinements were proposed in the Construction Contracts Amendment Bill first published in 2013. As part of the legislative process, 48 submissions were made to the Commerce Committee. There was general support for most of the amendments, but some parties expressed concerns on some of the changes. A documentary analysis of the Amendment Bills and submissions to the Commerce Committee was made to critically evaluate the changes proposed and establish if those changes were improvements. The findings show the major changes proposed include (i) removing most of the distinctions between the treatment of residential and commercial contracts under the Act, (ii) extending the scope of the Act to apply to contracts for certain professional services, (iii) removing the distinction between enforcement of payment determinations and of those relating to rights and obligations, and (iv) making the enforcement process more efficient. The findings also show that during a period of over two years from when the Bill was first introduced in January 2013, one other significant improvement - retentions are now to be held in trust - was made. A few proposals to further refine the Bill such as the suggestion to mandate retentions to be kept in a separate trust account were, however, not accepted. The Construction Contract Amendment Bill 97-3 was unanimously passed during the third and final reading in Parliament on 20 October 2015 with most of the amendments coming into force on 1 December 2015, those incorporating professional services on 1 September 2016, and the retention provisions on 31 March 2017. Royal Assent was given on 11 October 2015, leading to, on balance, a better Construction Contracts Amendment Act 2015.
\end{abstract}

Keywords: Adjudication, Construction Contracts Act 2002, Construction Contracts Amendment Act 2015, Construction Contracts Amendment Bill, New Zealand.

Paper type: Viewpoint

\section{Introduction}

Construction disputes were traditionally resolved through arbitration or the courts if a binding resolution was required. Over the years, arbitration, which was supposed to be quicker and cheaper became protracted, typically taking months or years, and became increasingly more expensive. Partly to address this problem, adjudication was first mandated to be incorporated in all construction contracts in the UK in 1998 through the Housing Grants, Construction and Regeneration Act 1996 (UK 1996 Act). Unlike arbitration, the duration of the adjudication process is statutorily provided. The periods provided are relatively short, typically quoted in days.

\footnotetext{
Copyright: Construction Economics and Building 2015. (C) 2015 David Finnie and Naseem Ameer Ali. This is an Open Access article distributed under the terms of the Creative Commons Attribution 4.0 Unreported (CC BY 4.0) License (https://creativecommons.org/licenses/by/4.0/), allowing third parties to copy and redistribute the material in any medium or format and to remix, transform, and build upon the material for any purpose, even commercially, provided the original work is properly cited and states its license.
}

Citation: Finnie, D. and Ameer Ali, N.A.N., 2015. The New Zealand construction contracts amendment Act 2015 - for better or worse? Construction Economics and Building, 15(4), 95-105. DOI: http://dx.doi.org/10.5130/AJCEB.v15i4.4544 
Both arbitration and adjudication are binding dispute resolution methods but unlike arbitration, an adjudicated dispute can subsequently be re-opened in court or, if the contract provides, in arbitration.

Since the UK 1996 Act came into effect in 1998 it has generally been hailed a success. Gaitskell (2005) for example suggests it has been a 'runaway success'. Adjudication has since been statutorily introduced in another 13 Commonwealth jurisdictions. In New Zealand adjudication was introduced through the Construction Contracts Act 2002 (NZ Act). The UK 1996 Act was further refined and replaced in 2009 by the Local Democracy, Economic Development and Construction Act 2009 (UK 2009 Act). Many of the new changes in the UK 2009 Act were features already found in the NZ Act.

As in the UK, the equivalent NZ Act has generally been well accepted. But ten years after it became operational in 2003, further refinements were proposed. The Construction Contracts Amendment Bill was introduced to the New Zealand parliament by the Hon Dr Nick Smith on 29 January 2013. The New Zealand Parliamentary website (New Zealand Parliament, 2015) states: "This Bill proposes amendments to the Construction Contracts Act 2002 concerning the disputes adjudication process." The Commerce Committee then invited public submissions. There were 48 submissions (including supplementary evidence) to Parliament on the Bill and four Supplementary Order Papers (SOPs) released between April 2014 and September 2015.

The final amended version of the Bill, the Construction Contracts Amendment Bill (97-3), was considered and reported by the committee of the whole House on 24 September 2015, then advanced to its third and final reading on 20 October 2015 when it was unanimously passed. The Bill received Royal Assent and passed as the Construction Contracts Amendment Act 2015 on 22 October 2015. The Act commences on 1 December 2015 except for the parts dealing with the inclusion of consultants, which commences 1 September 2016, and the introduction of retentions to be held in trust, which commences 31 March 2017.

Coggins, Fenwick Elliott and Bell (2010), when comparing some of the equivalent Acts in Australia against the NZ Act identified several advantages of the NZ Act, including (i) allowance for legal and non-legal representation, (ii) any pre-agreement of adjudicator to be non-binding, (iii) both parties to the dispute having the opportunity to defend themselves, (iv) maintaining some element of freedom of contract to agree any payment provision and making payment provisions in the Act only a default provision, and (v) allowing initiation of disputes both up and down the supply chain, insinuating the Act was fairly balanced.

If the NZ Act is already working relatively well, has had some of its provisions incorporated in the newer UK 2009 Act, and commentators have identified numerous advantages over some of the equivalent Acts found in Australia, why introduce an amendment Bill? Are the changes going to be an improvement?

\section{Summary of Key Changes}

The main changes proposed by the Construction Contracts Amendment Bill, New Zealand Legislation (2015) include:

- Removal of most of the distinctions between the treatment of residential and commercial contracts under the Act

o contractors can now suspended work as a result of non-payment under both residential and commercial contracts (residential contracts were previously excluded);

0 notices advising how to respond to payment and adjudication claims must now be served to both residential and commercial clients (previously only applied to residential contracts); 
o default payment provisions apply to both residential and commercial contracts, (residential contracts were previously excluded);

o charging orders can, however, still only be placed over commercial construction sites (maintaining the provisions in the original Act, the residential exclusion remains).

- extending the scope of the Act to also apply to contracts for design, engineering, and quantity surveying work, bringing the NZ Act in line with all other equivalent Acts around the world

- removal of the distinction between enforcement of payment determinations and of those relating to rights and obligations (previously only payment determinations could be enforced)

- making the enforcement process of adjudicators' determinations more efficient

After submissions to the Commerce Committee were closed, further SOPs were released, some of which introduced further changes. For example, SOP 052 released on 11 March 2015 introduced the new requirement for retentions to be held in trust and for adjudicators to serve their notice of acceptance as adjudicator within just two working days. Following numerous correspondence among construction professionals, the legal fraternity and officers of the relevant department and ministry including letters to the relevant Minister, SOP 106 was released on 22 September 2015 presenting Bill 97-3. This SOP maintained the requirements for retentions in trust, but following strong concerns expressed by industry professionals, academics, and lawyers, the requirement for adjudicators to serve their notice of acceptance as adjudicator within the impractical two days was sensibly removed. In addition, some other minor changes were incorporated such as the definition of a dispute under s.25(2) which was amended to include a "disagreement as to whether or not there has been a breach of a term of the contract."

The key changes found in the Amendment Bills are now further considered and reviewed in detail.

\section{Removal of most of the Distinctions between the Treatment of Residential and Commercial Contracts under the Act}

Section 10 of the NZ Act differentiates the way residential and commercial contracts are treated. These include (i) default provisions relating to payment, (ii) the ability to suspend work, and (iii) provisions relating to the issuing of charging orders on the construction site. These distinctions were provided allegedly to better protect residential clients who were assumed to be less likely to be aware of the provisions of the Act.

Provisions for default payment terms and the ability to suspend work for non-payment will now apply equally to both residential and commercial contracts. The Commerce Committee found no reason to distinguish between what was previously assumed to be the different circumstances of commercial and residential clients. The committee recommended that useful advisory notices under s.20(3) be provided to all clients, whether commercial or residential, and for both payment and adjudication claims. This was supported by most of the submissions including the New Zealand Law Society (2013), the Building Disputes Tribunal (2013), and the Arbitrators' and Mediators' Institute of New Zealand (2013). This change is seen as a sensible move. Even if there were some cases where commercial clients were more knowledgeable than residential clients, removing the distinction rationalises the Act into a common platform and makes it more efficient.

Section 31, which prohibits charging orders over residential construction contracts, was however, retained. Once a charging order over a commercial project is approved by an adjudicator appointed by an authorised nominating authority and enforced by the District Court, the 
property cannot be sold until the adjudicator's determination is satisfied. Some, for example the Building Disputes Tribunal (2013), felt this remaining distinction between residential and commercial contracts was artificial and unwarranted. They argued that it is unfair to contractors working directly for owners of residential dwellings, when those owners failed to pay amounts properly due. They also contended that, as residential property owners make up a quarter of all adjudication respondents, the Bill protected residential clients but not residential contractors. "The power imbalance" they said, "is generally in favour of the residential owner over the contractor as most contractors engaged in residential work are small 'one man' operators who do not have the benefit of income from multiple sources to cover them while disputes are resolved" (BDT, 2013 p.21). As a consequence many tend to accept less than they are owed to maintain cashflow.

The Arbitrators' and Mediators' Institute of New Zealand (2013, p.10) also questioned in basic terms: " $\ldots$ if an adjudicator determines that a residential owner is liable to pay a contractor, why should that owner's property not be subject to a charging order?"

In the final analysis it had to be a policy decision that determined whether this distinction on charging orders ought to be maintained. The Commerce Committee felt on balance that placing a charging order over a residential site could risk mortgage default. Their decisions may also have been influenced by political and social considerations; in this case the relative importance of continuing to house home owners without causing them to face the risk of mortgage default, as opposed to potential problems associated with delayed payment to the contractor. There is typically more sympathy towards a consumer than a business entity.

\section{Extended Scope of the Act to Apply to Contracts for Design, Engineering, and Quantity Surveying Work}

The NZ Act is the only Act among all 14 jurisdictions to exclude construction professional services within the scope of the Act. The Amendment Bill expanded the coverage to include construction professional consultants by inserting the following after s.6(1):

Construction work includes-

(a) design or engineering work carried out in New Zealand in respect of work of the kind referred to in subsection (1)(a) to (d) and (f):

(b) quantity surveying work carried out in New Zealand in respect of work of the kind referred to in subsection (1)(a) to (g).

Adjudication has been considered a successful form of alternative dispute resolution. Ameer Ali (2013) reports renowned lawyers and specialist construction judges calling it a 'runaway success' and 'revolutionary' in other equivalent Acts, all of which include construction professionals within their scope. Given also that there was significant support from the industry generally for inclusion of construction professional services, there appeared little reason to continue excluding construction professional services from the scope of the Bill. In a similar vein Britton (2015, p.20) describes leaving residential parties with litigation as their only option (as was the case under the original UK 1996 Act), as a less than ideal outcome for both parties. Bell (2014, p.12) comments that there remains a real difficulty in sensibly answering Judge Humphrey Lloyd QC's question posed more than a decade ago: "If adjudication is such a good idea, why does it not apply to all sectors of the construction industry?" The context of this question was in relation to the exclusion of some sectors such as the oil and gas sectors. There would nevertheless be even less reason to exclude construction professionals, especially when they have been included in all other jurisdictions without any reported significant adverse issues. 
The Building Disputes Tribunal (2013) said they "regularly receive inquiries from professionals seeking to recover fees in respect of services rendered, and from builders, developers and residential property owners disputing professional fee charges for the nature, scope or standard of professional services rendered." Bayley (2013) notes that where designers' contracts are novated (contractually passed) from the client to the builder, such as might happen under a design and build procurement, the designer is paid by the builder without the protection other subcontractors receive. This can lead to inconsistent remedies and provisions in the contracts between design and build contractors and the subcontractors and designers they engage. Pay when paid clauses could, for example, be retained in design consultancy contracts but not in construction work subcontracts under the current Act.

A number of submissions including those from Building Disputes Tribunal (2013), argued that incorporating only 'design or engineering work' and 'quantity surveying work' is selective and rather artificial. Many construction projects include other construction professionals such as project management consultants, building consultants, land surveyors, interior design consultants, and landscape architects. The last two could arguably be assumed to be included within the scope 'design and engineering work' but not the first three. The equivalent Acts in Singapore, Malaysia, Western Australia and South Australia specifically include "project management" under the scope of consultancy work.

The New Zealand Institute of Architects (2013) was one of few submissions that objected to the inclusion of construction professionals in the Amendment Bill. They argued that disputes over design related issues are too complex for adjudication, given its strict timeframe and unspecified minimum competency standards. These concerns were echoed by one other submitter, Transpower (2013), who felt that because their projects were very large and complex, the limited timeframe would make adjudication inappropriate and, that where determinations are later overturned for matters other than payment, compensation may not prove satisfactory. The NZIA (2013, p.11) recommended that if the Act's coverage of adjudication is to be expanded to include design disputes, then eligibility criteria should be set specifically for adjudicators of design-related disputes. Bayley (2013, p.35) observed that "many adjudicators currently are relatively inexperienced and are not required to demonstrate on-going competency."

On the whole, again the decision had to be made as a policy decision. On balance, given the overwhelming support for inclusion of construction professionals and the absence of enough evidence showing it to be a difficulty in other jurisdictions around the world, the approach taken by the Commerce Committee to include construction professionals is laudable. At most it is redundant, but it may well help facilitate cash flow for construction professionals and enable expedient resolution of disputes between construction professionals and clients or design and build contractors.

While the NZIA's suggestion regarding enhancing adjudicators' eligibility criteria is laudable, it should be applied across all adjudicators and not just for those dealing with design issues. An anomaly that remains in the final amended Act, which is a missed opportunity, is the somewhat limited scope of construction professional services covered by the Act.

\section{Removal of the Distinction between Enforcement of Payment Determinations and of those Relating to Rights and Obligations}

The Amendment Bill alters s.28(3), making determinations over both payment and other matters enforceable through the courts. Previously the courts only had to "have regard" to determinations on rights and obligations, however the Commerce Committee stated they "consider this amendment reflects a key purpose of the bill" s.28(3)(4). 
Ameer Ali (2013, p.6) supports the removal of the current distinction which he suggests is peculiar to the NZ Act. There does not appear to be any rationale for its continued presence.

Given that the adjudication process has been successful, there is no reason to distinguish the enforcement of payment determinations and determinations relating to rights and obligations. In any case they are often inextricably linked.

\section{Making the Enforcement Process more Efficient}

The Amendment Bill s.74 reduced the time to appeal a determination being entered as a court judgment from 15 working days to five. The Arbitrators' and Mediators' Institute of New Zealand (2013, p.12) welcomed the more streamlined enforcement. The Building Disputes Tribunal (2013, p.24) saw no need for any process to oppose entry as judgment, believing instead that the three grounds for opposition under 74(2) (the amount payable has been paid, the contract is not a construction contract under the Act, or a condition imposed by the adjudicator has not been met) are not required.

New Zealand courts generally hear appeals where adjudicators have breached rules of natural justice or acted outside their jurisdiction (Thode and Hardy, 2014). Green (2012) highlights the case of Herbosch-Kiere Marine Contractors Limited v. Dover Harbour Board [2012] heard in the Technology and Construction Court (TCC), where the issue of natural justice was dealt with. Akenhead $\mathrm{J}$ found that an adjudicator had breached the rules of natural justice when he used a method to assess the sum due to the contractor under a final account that neither party had put to him and upon which they had not been given an opportunity to comment. The adjudicator was considered to be using his own experience and knowledge.

In response to a submission that the adjudicator could not be criticised for reaching a decision that was wrong either in fact or law, the TCC judge commented:

"What [the adjudicator] can be criticised for is deciding something not only on a basis which was not argued in the adjudication proceedings but also without giving either party the opportunity to address the point."

The TCC found that the adjudicator's approach and method had a clear and material financial effect on the decision and as such, the decision should not be enforced.

Bell (2014, p.7) highlights that the current practice, at least in Australia and the UK, is that courts are upholding determinations which are made within an adjudicator's jurisdiction, even where they are erroneous. He then cites Mullins J in McNab Developments v MAK Construction Services (2013) who held that "... even though the adjudicator appears to have made errors in the construction of the subcontract, they are not jurisdictional errors that enable [the plaintiff] to obtain the declaratory relief it seeks."

In any of these cases and instances the robustness of the courts to enforce the adjudicator's determinations is commendable. Adjudication is, after all, meant to expedite cash flow and provide a quick dispute resolution process. The amendment to reduce the time to appeal a determination being entered as a court judgment will lead to even greater efficiency and is a welcome improvement.

\section{Appointment of the Adjudicator and Pre-adjudication Conferences}

Preventing parties from pre-selecting their adjudicator helps achieve a quality outcome by aligning the right adjudicator with the dispute. Section 33(3) of the original Construction Contracts Act 2002 already enables this: 
An agreement about the choice of an adjudicator or a nominating body or an authorised nominating authority is not binding on the parties to the adjudication if that agreement was made (whether under the relevant construction contract or otherwise) before the dispute between them arose.

However to also prevent ambush by the claimant during the process of appointing an adjudicator, Bayley (2013) recommends replacing the current process where parties can choose to adopt any option in selecting an adjudicator, to one with a hierarchy using a 'failing which' sequence of selecting an adjudicator under s.33(1).

He argues that the sequential approach can help prevent a claimant ambushing a respondent. Currently a claimant may spend weeks or months preparing an adjudication claim and jump straight to s.33(1)(d) requesting a nominating authority to appoint an adjudicator. The Act does not specify any timeframe for adjudicators to give their notice of acceptance to act as adjudicator, but to only notify their willingness and ability to act. However the Authorised Nominating Authorities may well have procedures instructing their adjudicators to serve their notice of acceptance immediately. Potentially the first time the respondent may become aware of the claim is when they are served the adjudicator's willingness to act (s.35(1)), adjudicator's notice of acceptance (s.35(2)), and the adjudication claim (s.36(1)), all within one working day. The respondent will in turn then need to respond to the claim in writing within a maximum of five working days.

The first version of the Amendment Bill (97-1) contained a proposal for a mandatory preadjudication conference to be held. However, as then worded, the conference was required to be held only after the adjudicator was appointed, and to be used merely for answering questions and not necessarily for explaining the adjudication process, the party's rights and obligations, and other options and details.

Bayley (2013b) and Ameer Ali (2013) made strong submissions supporting this amendment in principle. Ameer Ali (2013) also made submissions to correct what he suggested was an error. He proposed the pre-adjudication conference be held before the adjudicator serves the notice of acceptance and not after. This would then enable the adjudicator to explain the adjudication process to the parties (who may well be ignorant of the intricacies involved) and allow the parties to think through their disputes before the strict adjudication clock starts ticking when the adjudicators serve their notice of acceptance. Bayley elaborates that the pre-adjudication conference could also be used to deal with a number of issues such as establishing clearly what issues are to be adjudicated, potentially consolidating disputes, organising a timetable, ensuring the adjudicator's formal appointment terms are agreed, and fees paid. Bayley also suggests that such practice, if done without any fee payment, would not cost the parties anything except their time. If necessary, such conferences could even be held virtually through video or audio conferencing. More importantly, as a result of the meeting and briefing, there is the possibility of the parties resolving the dispute amicably, such as through negotiation or mediation.

The adjudicator should not be acting as mediator or negotiator in adjudication, but before the adjudication process starts, an altruistic adjudicator would be doing the industry and parties a service by briefing the parties on what might be an arduous process to come, once the official adjudication process starts. The parties would have been briefed that once the adjudicator serves the notice of acceptance, the dispute passes out of their control and transfers into the hands of the adjudicator.

Most of the other parliamentary submissions either made no comments on this amendment or were against the introduction of a mandatory pre-adjudication conference. Several submissions contended that the exercise would add time and cost, the assumption being the adjudicator would charge for the time spent during the pre-adjudication conference and not offer it as a 
public service. The Commerce Committee eventually recommended removing this provision. They explained their rationale for removing it in the commentary section of the Amendment Bill:

\section{Pre-adjudication conference}

We recommend deleting clause 15 . As introduced, the bill proposes mandatory pre-adjudication conferences. We believe this would add cost and delay adjudication. The Act already allows adjudicators to hold conferences, and making them mandatory is unnecessary. We believe prescribed forms would be a more effective way of informing parties of their rights and the standard procedures involved in adjudication.

Following this however, somewhat surprisingly, in the subsequent version of the Amendment Bill (SOP 52), the Minister Hon Nick Smith added another new provision which was never deliberated. Section 35 required the adjudicator to serve the notice of acceptance within only two working days. This would be an unworkable timeframe for confirming terms of engagement, arranging security for fees, checking for conflicts of interest, and potentially consolidating disputes. It would also have practically prevented adjudicators from holding any pre-adjudication conferences. Some adjudicators (see Bayley, 2013), who routinely call for a pre-adjudication conference, noted a high success rate of parties reaching their own settlement, avoiding adjudication all together before the notice of acceptance is served by the adjudicator.

Following strong concerns expressed by a number of construction professionals, lawyers and academics, the onerous restriction for adjudicators to serve their notice of acceptance within only two working days was eventually removed in SOP 106 issued on 22 September 2015 (Bill 97-3) which was the version passed in Parliament on 20 October 2015. As a result of this retraction, adjudicators can continue to hold pre-adjudication conferences and deal with the various preliminary issues suggested earlier. The proposal by Bayley (2013) to create a hierarchical process when appointing adjudicators was however not adopted. The wording in the final form is not fatal to ensuring an effective process of appointing an adjudicator.

\section{Retentions and other Security of Payment Methods}

Widespread concern has existed across the construction industry in New Zealand about potential abuse of retention monies, particularly where money was owed by head or main contractors to their subcontractors. The relatively recent collapse of one of New Zealand's major contractors, Mainzeal, highlighted how head contractors could use retention monies as free working capital, enabling them to remain operating even after they effectively become insolvent. In their submissions, Building Disputes Tribunal (2013), Master Plumbers Gasfitters and Drainlayers (2013), FloorNZ (2013), and the Specialist Trade Contractors Federation (2013) all put forward proposals mandating retentions to be held in trust accounts, as a means for securing payment of retentions.

SOPs 52 and 106 proposed a new subpart (2)(A) requiring parties to a commercial construction contract to hold retention monies in trust for the benefit of the party from whom it is deducted. While early proposals only applied to retentions from subcontractors, the Amendment Bill provides the application to all retention monies, including those retained by the client from the head contractor. Some of the parties also proposed that there were a number of key features of the new provisions that ought to be refined.

The Amendment Bill requires the retention monies to be held in trust but does not require that they be held in a separate bank trust account or lawyer's trust account. The argument against the stricter proposal for the retention monies to be held in a separate trust account was that it would be procedurally too complex to implement and monitor. It was argued that in the event of insolvency, the monies will already be protected from being paid to other creditors under existing trust laws. The parties holding the retention monies must however be transparent in 
their reporting of the funds. This includes keeping appropriate records and making these records available within reasonable time and without charge. The retention monies can only be used to rectify defects and cannot be used as cashflow or for paying other creditors.

Penalty interest may be claimed for late release of retentions at an amount prescribed by regulation, unless otherwise agreed through the contract. The construction contract cannot be amended to avoid compliance with the new provisions and the prohibition of conditional payments would, under the Amendment Bill, apply equally to payment of retentions. The holder of the retentions will be free to invest the money in accordance with the Trustee Act 1956, but they must cover any losses. The new provisions will apply only to commercial construction contracts where the amount of retentions is considered more than the de minimis amount - an amount deemed so small that the provisions are not required. This amount will be prescribed through regulations.

An alternative to holding retentions is the use of bonds in lieu of retentions. The New Zealand Contractors' Federation (2013) noted that small firms may struggle to raise bonds but, paradoxically, this is so when their cash-flow is often reduced by money tied up in retentions. They recommended that insurance products that provide bond facilities should be readily available to a contractor in lieu of retentions. However, it should be noted such facilities would add cost to the project. The New Zealand Contractors' Federation (2013) made two other suggestions to protect subcontractors in the event the head contractor becomes insolvent. Firstly, they recommended adding a provision enabling contractors to remove their tools and equipment from a site within a maximum period of 24 hours in the event the head contractor is placed into liquidation.. Second, they recommended payment claims and their certificates become exempt from being considered voidable transactions under the Companies Act 1993, which would otherwise allow liquidators to claw-back payments to creditors (e.g. subcontractors) for up to two years before the head contractor's liquidation. Liquidators only need prove that the head contractor was not able to remain solvent when payment was made (Shaw, 2014).

There is little doubt that incorporating provisions for holding retention monies in trusts (as promoted by a significant number of submissions on the Amendment Bill) has the potential to greatly improve cashflow and financial security. However the overall benefit can only be established once implemented and the inconvenience to contractors and clients such as developers, of holding retentions in trust is taken into account. Passage of time will also determine if other security methods, such as bonds, replace retentions. Unlike New South Wales, which introduced the requirement for contractors to hold retentions in trust accounts, the New Zealand government took the light-handed approach of allowing contractors to hold retentions from multiple projects in a single bank account. The issue of co-mingling of funds from various construction projects, or the daunting task that may face any subcontractor wanting to obtain its entitlement to retentions in the event the head contractor becomes insolvent, remains to be addressed (Simpson Grierson, 2015).

\section{Conclusion}

The Construction Contracts Amendment Act 2015 generally improves what is already considered an effective piece of legislation - the Construction Contracts Act 2002. Coverage is now expanded to include designers and quantity surveyors; all determinations, whether those on payment or rights and obligations will now be enforceable through the courts; and the timeframe to appeal is reduced from 15 to five working days. Substantially removing the distinction in the treatment between residential and commercial contracts means commercial clients will now be better advised on how to respond to claims through explanatory notices (previously limited to only residential contracts), default payment provisions will apply to both residential and commercial construction contracts, and residential contractors will equally be able to suspend 
work for non-payment. However, commercial construction sites can be subject to charging orders while residential construction sites are exempted.

Some recommendations found in submissions to the Commerce Committee were incorporated in the SOPs and subsequent versions of the Bill (97-2 and 97-3) and the eventual Act that was passed as the Construction Contracts Amendment Act 2015. These include removing the impractical two-day requirement for adjudicators to serve their notice of acceptance. Even more significantly, contractors are now protected from their client becoming insolvent through their retention monies being secured in trust. Likewise subcontractors are protected against head contractors. How easily they will be able to retrieve their monies held in a mingled fund in the event the party holding the retention money goes into liquidation remains to be seen. The call for retentions to be placed in a separate trust account was among the few outstanding concerns not accepted by the Commerce Committee.

A few other recommendations worthy of consideration that were not adopted include project managers not being included under the umbrella of consultants that were now brought within the remit of the Amendment Act and the recommendation to create a hierarchical system when selecting an adjudicator - starting from agreement between parties, to the claimant unilaterally instructing an authorised nominating authority to select an adjudicator. This would have helped prevent a claimant ambushing a respondent by serving the latter with the adjudicator's willingness to act, the adjudicator's notice of acceptance, and the adjudication claim all in one day, while giving the respondent only five working days to respond in writing.

Given the changes proposed and possibility of dealing with more complex matters, statutorily specifying minimum competency standards would also have helped enhance the standards of the adjudication process. This can however still be achieved by way of publishing regulations to the new Construction Contracts Amendment Act 2015.

On balance, the Construction Contracts Amendment Act 2015 can be said to be for the better.

\section{References}

Ameer Ali, N., 2013. Submission to the commerce select committee on the construction contracts amendment bill 2013. [online] Available at:

http://www.parliament.nz/en-nz/pb/sc/documents/evidence/50SCCO EVI 00DBHOH BILL11975 1 A348553/naseem-ameer-ali [Accessed 29 April 2015].

Arbitrators' and Mediators' Institute of New Zealand, 2013. To committee members. [online] Available at: http://www.parliament.nz/resource/en-nz/50SCCO EVI 00DBHOH BILL11975 1 A344145/ 90cba8f206368fa0461e2a29006933501df4f292 [Accessed 29 April 2015].

Bayley, G., 2013. Construction contracts amendment bill submission to the commerce committee by geoff bayley. [online] Available at: http://www.parliament.nz/resource/en-nz/50SCCO EVI 00DBHOH BILL11975 1 A350025/ 664fbf91bfa47ce8b332235f7da382b1c432129f [Accessed 29 April 2015].

Bayley, G., 2013. Construction contracts amendment bill submission to the commerce committee by Geoff Bayley supplementary 1. [online] Available at: http://www.parliament.nz/resource/ennz/50SCCO EVI 00DBHOH BILL11975 1 A359250/4b14fe42f6f29bf27bfbd8ad5c23a3aef115a9c1 [Accessed 29 April 2015].

Bell, M., 2014. Beyond the nutcracker: international harmonisation of construction industry payment legislation. Society of Construction Law UK, 188.

Building Disputes Tribunal., 2013. Construction contracts amendment bill (no 97-1) submission from building disputes tribunal (NZ) limited 25 july 2013. [online] Available at: http://www.parliament.nz/resource/ennz/50SCCO EVI 00DBHOH BILL11975 1 A345327/71d4d1e8ab2bdcdb475958fb86d5cd91d727dfac [Accessed 29 April 2015].

Britton, P., 2015. Adjudication and the 'residential occupier exception': time for a rethink?. Society of Construction Law UK, 193.

Coggins, J., Fenwick Elliott, R. and Bell, M., 2010. Towards harmonisation of construction industry payment legislation: a consideration of the success afforded by the east and west coast models in Australia - plus addendum. Australasian Journal of Construction Economics and Building, 10(3), pp.14-35. doi: http://dx.doi.org/10.5130/ajceb.v10i3.1804 
FloorNZ, 2013. Construction contracts amendment bill 97-1. [online] Available at: http://www.parliament.nz/resource/en-nz/50SCCO EVI 00DBHOH BILL11975 1 A345332/ 3ebb8b4a12c00c350b1853922ea218d526917d31 [Accessed 29 April 2015].

Gaitskell, R., 2005. Adjudication: Its Effect on other Forms of Dispute Resolution (The UK Experience). Proceedings of the International Conference and Forum on Construction Industry Payment Acts and Adjudication, Kuala Lumpur.

Green, J., 2012. Natural justice again! Buildlaw. 13. [online] Available at: http://www.buildingdisputestribunal.co.nz/RESOURCES/BUILDLAW/BuildLaw+Issue+13+March+2012.h $\underline{\mathrm{tml}}$ [Accessed 29 April 2015].

Herbosch-Kiere Marine Contractors Limited v. Dover Harbour Board [2012] in Buildlaw, 2012. Natural justice again!!. [online] Available at: http://www.buildingdisputestribunal.co.nz/site/buildingdisputes/files/BuildLaw/ Issue $\% 2013 / / 6 . \% 20$ Natural\%20Justice\%20Again!.pdf [Accessed 29 April 2015].

Master Plumbers, Gasfitters and Drainlayers NZ, 2013. Commerce select committee submission on construction contracts amendment bill 97-1. [online] Available at: http://www.parliament.nz/resource/ennz/50SCCO EVI 00DBHOH BILL11975 1 A344188/08bc293d588e906267f3a3551ae10eddfaa78144 [Accessed 29 April 2015].

New Zealand Contractors' Federation, 2013. Requested submission to the commerce select committee on construction contracts amendment bill 2013. [online] Available at: http://www.parliament.nz/en$\mathrm{nz} / \mathrm{pb} / \mathrm{sc} /$ documents/evidence/50SCCO EVI 00DBHOH BILL11975 1 A344937/new-zealandcontractors-federation [Accessed 29 April 2015].

New Zealand Legislation, 2015. Construction Contracts Amendment Bill 97-1, 97-2, and 97-3. [online] Available at: http://www.legislation.govt.nz/bill/government/2013/0097/latest/versions.aspx [Accessed 23 October 2015].

New Zealand Parliament, 2015. Construction contracts amendment bill. [online] Available at: http://www.parliament.nz/en-nz/pb/legislation/bills/00DBHOH BILL11975 1/construction-contractsamendment-bill [Accessed 23 October 2015].

New Zealand Institute of Architects, 2013. Construction Contracts Amendment Bill Commerce Select Committee - additional information tabled. [online] Available at: http://www.parliament.nz/resource/ennz/50SCCO EVI 00DBHOH BILL11975 1 A359246/92bcc6991abcf19c7ac0b5d60cc3323996cddd95 [Accessed 29 April 2015].

New Zealand Law Society, 2013. Construction contracts amendment bill. [online] Available at: http://www.parliament.nz/resource/en-nz/50SCCO EVI 00DBHOH BILL11975 1 A345166/ b99cd86e5fd08408c1fd2a9e644b920babc8bd6a [Accessed 29 April 2015].

Shaw, K., 2014, January/March. Voidable transaction changes?. Build Magazine, 140, 76- 77. [online] Available at: http://www.branz.co.nz/cms show download.php?id=c5ceb03ad9c2d1b1e15bb1cb07390fae57656bb4 [Accessed 29 April 2015].

Simpson Grierson, 2015. The construction contracts amendment bill - nearly there!. [online] Available at: http://www.simpsongrierson.com/construction-contracts-amendment-bill/ [Accessed 29 April 2015].

Specialist Trade Contractors Federation, 2013. Submission on the construction contracts amendment bill. [online] Available at: http://www.parliament.nz/resource/en-nz/50SCCO EVI 00DBHOH BILL11975 1 A344327/ 49d8bbe39d527b6ac38820e4a19ef939f3b98bcc [Accessed 29 April 2015].

Thode, E. and Hardy, M., 2014. Finality of adjudication under the CCA. (2014, September). NZLJ 309.

Transpower, 2013. Submission to the Commerce Committee in relation to the Construction Contracts Amendment Bill. [online] Available at: http://www.parliament.nz/en-nz/pb/sc/documents/evidence/ 50SCCO EVI 00DBHOH BILL11975 1 A344880/transpower-new-zealand. [Accessed 23 October 2015] 